\title{
The View from the Dean's Office
}

\section{Presenters}

Andrew Keck, Executive Director of Strategic Initiatives,

Perkins School of Theology - Southern Methodist University

Beth Bidlack, Director of Library Services, Castleton University

(formerly Associate Dean of Academic Affairs, Union Theological Seminary)

Debbie Creamer, Senior Director of Accreditation, The Association of Theological Schools

\begin{abstract}
With leadership skills gained from careers in theological libraries and experience from working closely with academic administration, theological librarians can be invited to work more directly within a seminary administration-either in administrative roles added to library roles or wholly administrative roles. This panel presented insights from three library colleagues who moved from library to seminary administration. The panel addressed the focus of these administrative roles, points of intersection between academic administration and libraries, how the library is viewed from these offices, and strategies for working together.
\end{abstract}

\section{PANELIST 1: DEBBIE CREAMER}

My entry into academic administration happened quickly. I was serving as an (interim) library director and was asked to direct my school's ATS self-study process, largely because the director ten years earlier had been the library director (and, I think, nobody else wanted to do it!). This role shifted my perspective not only on my institution (as I got to see a bigger picture, from coordinating the comprehensive accreditation review) but also on the central role of librarians in my institution-as it helped me to recognize skills and expertise that comes with the work of librarianship that I hadn't even noticed before I started shifting my role into other areas. And, with each successive step into academic administration (from accreditation liaison to distance learning director, associate dean, academic dean, and now in my role with ATS), I've continued to be even more convinced that librarians have a significant role to play in academic administration. 


\section{Points of intersection:}

- I didn't know this as a librarian (but maybe you do), and folks at my school didn't know this about librarians (and probably yours don't), but I believe that the work of administration (including accreditation, assessment, and deaning) resonates more closely with library work than it does with traditional faculty responsibilities.

- Most administrators at our schools were not trained to be administrators (especially if they came to their administrative role from faculty or from outside of higher education)but many of us were, either in library degree programs or on the job.

- ATS did a study a number of years ago asking new faculty what their doctoral programs had prepared them to do, and what they were actually doing in their jobs (as faculty, not even as administrators). Not surprisingly, doctoral programs are (typically) great at preparing folks for scholarship, okay at preparing folks to teach, but awful at preparing folks to do administration.

- No one at my institution knew that not only had my MLIS program included specific courses on administration, but also that my daily work as a library director was administrative in ways that translated to other contexts as well. As a result, I had to learn how to be a translator or interpreter.

- When I translate some typical library skills into broader or more accessible language, here are some of the ways we are prepared to lead or manage academic administrative work:

- Organizing information (obviously)-but not in a filing cabinet

- Curating information (deciding what is more or less relevant/ needed, seeking the information that is lacking, choosing between reputable and less-reputable sources, dealing with contradictory sources, building a narrative, creating pathfinders...)

- Resourcing people-at all the levels (guessing what they need and making it available before they know they need it; providing them with the tools they need to do their work; 
helping them get and stay interested in what they're doing)

- Evaluation (e.g., we do it as a normal part of collection management-is this book worth the expense, is this database important to us, is this subscription redundant, should this item be weeded-and as part of the research process-is this the best source, does this make a compelling argument, is this a credible resource)

- Planning (ditto: we are used to thinking of short-term and long-term needs of our stakeholders and how to get from A to B, whether it's a collection shift or new strategies for engaging our community)

- Specific technical skills: (e.g., supervising people, dealing with technology, managing a budget, project-management, long-range planning (the library is perhaps the longestrange part of your institution!)

\section{How the library is viewed:}

- At my previous institution, as I moved into broader administrative roles, my non-librarian colleagues started to see that I (Debbie) was good at these things. I'm not sure they ever saw that "librarians" are good at these things. Even now, in my current context, I've discovered that many folks think about librarians on accreditation visits as "single-use tools" while I think of them/us as "Swiss army knives" (i.e., we're often good at all the things I listed above-planning, budgeting, staffing, governance, evaluation-in addition to libraries and technology).

- My sense is that one way to help shift these perceptions is to start showing your non-librarian colleagues a different picture of the library world. For example, if you have the chance to report to a faculty meeting or update the community on the library, don't just talk about materials-also talk about strategic thinking, or planning and evaluation, or adapting to change.

- It also helped me to recognize that sometimes people are just not thinking about the library at all (not dismissing it, just not noticing it). This is a bit like the reminder that people think about us less than we think they do, because we're all busy 
thinking (and worrying) about ourselves. Most times, folks weren't intentionally dismissing the gifts that library folks might offer to their work; they just weren't thinking about them. And, guess what? Librarians also know how to do PR and raise awareness, and offer access, and invite conversation!

- One other piece that helped me was to remember that folks often just repeat what they know (e.g., teachers teach the way they were taught, or the way they wish they were taught). It's quite possible that you and your library are significantly different from the librarians and library spaces that your faculty and other colleagues encountered earlier in their careers. Instead of assuming that they already know what we can do, we can help folks see (and, more importantly, experience) a different sense of what "library" or "librarian" is.

\section{Tips for how to work together:}

- Need to not just say, "I can do this" (or wait and wish people would ask you), but also to offer or demonstrate you can do this. So, for example, if you know the school is starting a strategic planning process or developing new HR policies, or any other area where your library skills translate into the larger institution, you can say "Would you like me to do this?" or even "I did this, is it helpful?” Most deans (and similar administrators) are exhausted and overworked, and thrilled to have a colleague who understands or is willing to lend a hand.

- Don't throw fuel on the fire of us vs. them. Faculty (and formerfaculty) can be great at winning arguments (some of them have PhDs in that!), or might get more invested in their side of the argument than in any sort of institutional change. And, bluntly, stop whining that they don't include you-I'm happy to whine with friends, but, when I do it at my institution, it doesn't make things better. Rather than thinking of sides, I'd rather imagine a spectrum (perhaps of folks who see the library's relevance to those who don't, or whatever the challenge is in your context), which then makes it easier to think about allies or advocates, or of shifting minds contextually (one situation at a time) rather than all at once. I imagine that I could learn a lot from public libraries-how did they become/stay relevant? In 
my neighborhood, the public library is a central resource-not just for "materials" (audiobooks, videogames, museum passes, etc.) but also for "services" (résumés, knitting, even wine tasting events). What could we learn from them, particularly in how they helped stakeholders know that they are valuable?

- Just as you shouldn't assume that members of your school's administration understand you (or, what you know/do/think) ... you also shouldn't assume you understand them (or, what they know/do/think). As I've worked on the redevelopment of the standards this past year, and had the privilege of listening to focus groups, I've continued to be surprised at how many misperceptions we all have of each other. I'd love to host conversations at schools along the lines of "what I wish you knew about my job." Yes, librarians are misunderstood and often undervalued. But so are most of the people you work with, in my experience.

- Related to this, you might ask yourself: Why do I want to do this? Sometimes I see folks who are interested in moving into administration as a way to get acknowledgement, to feel more important, to have greater voice. Others are looking for a better alignment of their gifts, or for a new way to serve. I think it's always a messy mix of both of these, but it's good to pay attention.

- As you lean into academic administration, try to shift your view-put the mission of the school at the center of your work, not the needs of the library alone. And maybe you've already done this, but you might want to practice being more explicit about it-for example, pay attention to when you use a word like "we" to see how often you mean "the school" (rather than just the library, the staff, etc.).

- At the same time, be cautious that they don't steal you away from the library, or at least continue to advocate for the needs of the library. Maybe the best thing you can do for yourself, and for your organization, is to make the library as good a library as it can be, help it thrive. 


\section{PANELIST 2: ANDREW KECK}

\section{Seminary administration has similarities to library admin- istration}

- Comprehensive view of the institution. Library and seminary administrations are both concerned about faculty, students, and curriculum. The specific interests of faculty make a difference in collection development, reserves, and design of assignments that make use of the library. Student preparation and the rigor of admission contributes to the work required for library, writing, and academic support. The curriculum determines the depth and breadth of theological and cognate disciplines that are emphasized.

- Strategic view of the institution. Libraries are acutely aware of issues on the financial side of the house, the penalties for deferred maintenance, and the importance of marketing and recruitment. We not only feel the brunt of an institution's successes and failures-we operate our own microcosm in the library. We too try to emphasize strategic thinking and innovation while avoiding the colorful animals: white elephant (miscalculating costs), golden calf (miscalculating value), red herring (miscalculating importance), and black swan (miscalculating likelihood).

- Long-view of the institution. Both have concerns about legacy and future generations of faculty, staff, and students. The library as institutional legacy that persists and adds increasing value to successive generations.

- A major difference in thinking about revenue versus budget allocation. Justifying a seminary budget is a different exercise than justifying a library budget.

\section{Libraries tend to not be "top of mind" in the dean's office}

- Administration is not as concerned about the library or library problems as the library director. There is a reason they hired you to be in the library. Most of us might prefer benign neglect to micromanaging but it's always good to have a partner in the dean's office both as an advocate (such as when you are start- 
ing a new program or trying to get recalcitrant faculty to turn in their reserve lists) and as a protector (when the CFO decides to cut student worker budgets across campus by twenty-five percent or the university thinks it can simply absorb your library).

- Not surprisingly, much of administration can be reactive. The dean's office tends to deal with turf and communication issues between departments, personnel issues, problems that cross multiple department lines, external relationships with donors, related organizations, and other university leaders.

- The proactive work of seminary administration tends the regular machinery of governance, communication, and finances.

\section{Library issues that gather the most attention in the dean's office}

- Budget and finances-especially around the expenses of staffing and the seemingly discretionary budget allocated to collections

- Faculty issues (course support, writing support, research support)

- Student issues-space and hours

- Alumni and other guests

\section{Opportunities for collaboration or how libraries can help dean's office}

- Bring solutions and ideas, not problems and complaints.

- Library budget and financial concerns require transparency and flexibility. You can generate a lot of good will by being flexible. For example, I sometimes would delay purchases at the end of the fiscal year to help with cash. Or project out for three yearsso the dean can see the impact of increasing journal prices.

- Provide good data and insights on students, curriculum (syllabus analysis), and faculty research. Who else on campus analyzes every syllabus? Who else sees and hears from a variety of students struggling to understand an assignment? Who else deeply knows about a faculty member's new project?

- Co-sponsor or support other activities. Offer library spaces for public events, displays, and speakers. 
- Network and intersect with campus IT, the university library, other libraries/institutions, alumni and the broader community. Through the course of our work, libraries interface with a variety of departments/individuals on campus, local/ national competitors, and serve a broader community beyond the campus. Deans are regularly shocked to find out who librarians already know or what we have heard about.

- The librarian can often find themselves as a confidant and partner of a dean because of our deep understanding of the institution and its overall context, ability to think strategically, and collection of resources that can be brought to bear.

\section{PANELIST 3: BETH BIDLACK}

Since the summer of 2016, I have been the Associate Academic Dean at Union Theological Seminary. I was recruited for this position because Union needed to undertake self-studies with the Association of Theological Schools (ATS) and the Middle States Commission on Higher Education (MSCHE), and I had experience with accreditation visits and assessment. I also brought administrative and interpersonal skills to the position. Prior to August 2016, I served as Director of the Burke Library, physically located at Union, but owned and managed by the Columbia University Libraries. As Associate Academic Dean, in addition to re-accreditation, my focus has been on assessing student learning and improving the overall student experience.

\section{The Burke Library and \#LoveInAction}

While at the Burke Library (2013-2016), I observed Union students during the start of the Black Lives Matter Movement. They were organizing and participating in marches on a regular basis. Like most generations of Union students, they were committed to social justice, but they seemed to know little about Union's long history of activism. In 2014, I hired a Public Services Librarian who had a background in public history and archives. She and I shared a commitment to connecting the current generation of students with Union's long history of activism. 
Hence, the library began its efforts to support the \#LoveInAction initiative at Union. The name of the initiative harkens back to the words of Cornel West, a renowned public intellectual and author of many books, including Race Matters, who said, "Never forget that justice is what love looks like in public." \#LoveInAction became the focus of Union's Student Senate meetings. The students mobilized in one of Union's classrooms and named the space the "Love Hub." Here they strategized, provided support to each other, and rested after marches. It was the place where people could donate food and other items needed to support students in their work.

As the library staff and I learned more about the students' efforts, we connected some of them to relevant archival collections, including the Student Interracial Ministry collection, and to Union's alums. The Student Interracial Ministry (SIM) began in 1960. It was a ministry in which students, congregations, and community members from racially diverse backgrounds would gain a greater appreciation and understanding of each other (see https://clio.columbia.edu/catalog/4492714). In addition, library staff worked with Union's alumni/ae relations office to identify alums who were part of SIM and similar projects and initiatives and to connect the current students with these alums. As a library, we developed a co-curricular program to support \#LoveInAction. A few students curated small exhibits of archival materials and moderated panel discussions between current students and alums that focused on racial justice (see https://blogs.cul.columbia.edu/burke/).

At the end of the academic year, we gathered a few of the students and reviewed the degree program goals and learning outcomes for the Master of Divinity degree at Union. We talked about how their \#LoveInAction work and the library's co-curricular support helped them achieve some of the MDiv learning outcomes. For example, our efforts helped students achieve the following: 


\section{Religious Heritage}

1.1. Demonstrates an ability to identify, describe, analyze, and to interpret biblical texts in their literary, historical, and multi-religious contexts.

1.2. Demonstrates an ability to identify, describe, and to discuss significant periods, persons, and developments in the history of the Christian tradition(s).

1.3. Demonstrates an ability to recognize, explain, and to critically evaluate major theological themes, issues, and perspectives in Christian thought.

\section{Cultural Context}

3.1. Demonstrates an ability to work with persons of diverse backgrounds, to learn from differences, and to articulate one's own cultural and social perspectives with acknowledgment of their limitations.

3.2. Demonstrates an ability to articulate contextually informed and world-engaged theological perspectives.

3.3. Demonstrates an ability to analyze and address contemporary ethical issues from Christian and interreligious perspectives.

\section{Capacity For Ministerial And Public Leadership}

7.1. Demonstrates development of a professional identity that is connected to the student's abilities, aspirations, and faith tradition.

7.2. Demonstrates a theologically and professionally informed model and style of ministry within particular ministerial contexts.

8.1. Demonstrates interpersonal insight and an ability to listen actively, communicate effectively, and to interact with others with honesty, empathy, compassion, and respect.

9.1. Demonstrates the ability to represent and lead a community or organization in and through public and communal contexts such as worship, preaching, congregational pastoral care, public prayer, advocacy, teaching, written communication, and/or public speaking. 
During our discussion, we realized that the \#LoveInAction initiative and the library's support of it helped students make progress toward most of the MDiv learning goals and outcomes. The students left with a deeper appreciation of our efforts and we left with a deeper commitment to our roles as facilitators, teachers, and mentors. The library's services and collections took on greater value and impact.

Eventually, the "Love Hub" closed, and the materials from it were added to the Union archives housed at the Burke Library. In addition, we set up a portal whereby students could deposit digital materials documenting their activities in the Black Lives Matter Movement and \#LoveInAction initiative into Union's archives. We talked about whose voices were missing from the archives and the importance of making sure those voices are represented in the future.

The \#LoveInAction experience prompted me to reflect more deeply on student experiences and co-curricular offerings that are so very important to the formation and education of students. As the Associate Academic Dean, I continue to reflect on these matters. For three years, I have led Union's efforts to assess student learning and have collected data on progress toward the degree program goals and learning outcomes for our degree programs. I participate in midprogram review conferences for our MDiv students and talk to students on a regular basis. I have learned much from them-their hopes, dreams, and concerns; what skills and experience they need as they leave Union. I have seen the challenges this generation of students faces-increasing student debt, the need for greater awareness about reasonable accommodations, and the growing need for support of their mental and spiritual health. These are issues that are often not addressed in the classroom. I have become more convinced of the need for libraries to offer co-curricular activities and other means of support for students.

\section{II. “New Librarianship”}

Now more than ever, I am convinced that the library has experience and expertise to bring to students. This conviction has been strengthened by my participation in a MOOC on "New 
Librarianship" designed by R. David Lankes. "New Librarianship" recasts librarianship and library practice using the fundamental concept that knowledge is created though conversation. New librarians approach their work as facilitators of conversation; they "seek to enrich, capture, store, and disseminate the conversations of their communities." According to Lankes, "The mission of librarians is to improve society through facilitating knowledge creation in their communities." ${ }^{2}$ He revisions libraries from the model of bringing information to the community to "pushing knowledge from the community outward."

As I reflect back, I would say that the Burke Library's support of the \#LoveInAction initiative is one example of facilitating conversations within a community, of connecting people not just with materials (in this case, archives), but also with other people (in this case, alums). The initiative was about addressing the needs of the community. The library's work helped to "enrich, capture, store, and disseminate the conversations" of the Union community. Librarians are network builders who strengthen communities. In short, we must be the ones who facilitate the creation of something new based on the needs of the community in which we are located. Often, this means we must leave our four walls and embed ourselves within the communities that we serve.

Lankes notes that, as librarians, we need to be facilitators of conversation. This means bringing people in our communities up to speed so that they can participate in conversation, training, and knowledge. It means creating environments where people feel safe (including physical safety and online privacy). And it means motivating people, sparking their curiosity, and creating inspiring spaces-physical and virtual. Librarians are tool builders (software, websites, pathfinders, groups/events, repositories, etc.), a skill that often brings value to our communities. Librarians are problem-solvers, a trait they often share with administrators. Librarians are constantly learning and are resources and role models for lifelong learning. Think for a moment about how much you have learned and changed over the past year or two, over the past decade, over your career.

I'd like to conclude with some questions. What is the 
framework for conversations in our communities? How can we revision the library to be at the center of those conversations? How can we revision our work as library staff to be facilitators of important conversations on our campuses? How do our skill sets (project management, interpersonal skills, assessment skills, problem solving) equip us to be facilitators and leaders in addressing concerns, issues, and problems? What tools do our communities need? What are the most pressing needs of our communities? I invite you to reconsider the synergies between the library and dean's office, between library staff and administrators, and to live into David Lankes's concept of “new librarianship.”

\section{ENDNOTES}

1 R. David Lankes, “The Atlas of New Librarianship Online," accessed October 28, 2019, https://davidlankes.org/new-librarianship/the-atlas-of-new-librarianship-online/.

2 R. David Lankes, “New Librarianship,” accessed May 1, 2019, https://davidlankes.org/new-librarianship/.

3 R. David Lankes, “Library as Movement,” July 23, 2019, https:// davidlankes.org/library-as-movement/. 